\title{
The Level of Educational Leaders Commitment to the Organizational Intelligence Dimensions in the Saudi Educational Institutions from the Perspective of Teaching Board Members and the Educational Leaders
}

\author{
Khawla Husain Taha Alaiwa \\ Department of Education \\ Faculty of Education - Hail University, Assistant professor \\ Hail, Saudi Arabia
}

Doi: 10.19044/esj.2018.v14n7p234 URL:http://dx.doi.org/10.19044/esj.2018.v14n7p234

\begin{abstract}
The current study aims to identify the level of educational leaders commitment to the organizational intelligence in the Saudi educational institutions from the perspective of the teaching board members and the educational leaders, also identifying the organizational intelligence dimensions and its domains. To achieve the study objectives, the researcher applied the descriptive analytical approach. The study has been applied over a random sample of educational leaders and teaching board members in the Faculty of Education of Ha'il University. The study sample included (102) members. The study concluded that there is a high level of commitment from the educational leaders to the organizational intelligence. In the end, the researcher recommended the need to continue following a methodology based on the exploitation of human resources in the institution.
\end{abstract}

Keywords: Educational leaders, teaching board members, organizational intelligence

\section{Introduction}

Organizational intelligence has been given a great deal of attention in the educational organizations perspectives. Many educational institutions were affected by the organizational intelligence concept in order to understand the external environmental changes, as well as to respond to what guarantees their survival and sustainability in the face of rapid competition between the educational institutions, through the utilization of the institution's internal capabilities, therefore; educational institutions are concerned with capacities 
and their enhancement due to their impact on the success of the institution as a whole. (Hanouneh, Hammad, 2006)

Organizational intelligence represents an appropriate method to make use of information and teaching staff capabilities in an educational institution, through which the institution can adapt to the external environment in appropriation with the available resources and capacities, this clearly represent the concept of organizational intelligence. (Durrah, 2015)

The greater the challenges are, the more preparations are needed, along with an increased need to find mechanisms and inputs that help the educational institutions increase their preparations to deal with the challenges they face. Especially those related to the cognitive and technological aspects, in the context of maximizing the use of intangible resources, such as intelligence, innovation, knowledge and learning, in order to help the institution adapt and meet the requirements of the contemporary knowledge society. (Al-Abbadi, 2012)

Emerging from this, the current study was conducted to identify the level of educational leaders' commitment to the organizational intelligence dimensions in Saudi educational institutions.

\section{Study problem and questions}

With the rapid scientific development and the revolution of technology and knowledge that controls the educational environment, the educational institutions' need increases to respond quickly to the unprecedented and unpredictable environmental changes of learning and teaching, which by its turn led to the need to adhere to the organizational intelligence dimensions to overcome the external environmental changes and keep pace with the cognitive and technological revolutions.

Therefore, the study problem seeks to clarify the truth of the educational leaders' commitment to the organizational intelligence dimensions in Saudi educational institutions from the perspective of the teaching board members and educational leaders themselves.

\section{The study main question}

Are the educational leaders committed to the organizational intelligence dimensions in Saudi educational institutions? And to which level are they committed to them?

\section{The main question sub-questions}

1. What are the organizational intelligence dimensions?

2. What are the organizational intelligence concept main trends? 


\section{The study main objective}

Verify the educational leaders' commitment to the organizational intelligence dimensions in Saudi educational institutions from the perspective of teaching board members and the educational leaders themselves.

\section{From the study main objective come the following sub-objectives}

1. Identifying the organizational intelligence concept in Saudi educational institutions.

2. Identifying the organizational intelligence dimensions in Saudi educational institutions.

3. Identifying the main domains that adopted the organizational intelligence in Saudi educational institutions, and pointing out the main trends that handled the concept of organizational intelligence.

\section{Study importance}

\section{The current study importance emerges from the following}

1. This study aims to raise the awareness of educational leaders in Saudi educational institutions about the importance of commitment to the organizational intelligence dimensions as an appropriate tool to overcome the external challenges that face their educational institutions.

2. The majority of previous studies didn't focus on the direct impact of the educational leaders' commitment to the organizational intelligence dimensions in Saudi educational institutions.

3. This study is an important source for future studies regarding the capabilities of organizational intelligence dimensions and their impact on the educational institutions.

\section{Study model}

Independent variable Dependent variable

Organizational intelligence dimensions

$\begin{array}{cc}\text { Knowledge tool } & \begin{array}{c}\text { Educational leaders in Saudi } \\ \text { educational institutions }\end{array}\end{array}$

Competitiveness and organizational excellence

By the researcher 2017

\section{Study hypothesis}

There is a commitment of statistical significance at sig. $(\alpha=0.05)$ by the educational leaders to the organizational intelligence dimensions in Saudi educational institutions. 


\section{Study sub-hypotheses}

1. There is a statistical significance of the educational leaders' commitment at sig. $(\alpha=0.05)$ to knowledge management dimension in Saudi educational institutions.

2. There is a statistical significance of the educational leaders' commitment at sig. $(\alpha=0.05)$ to the organizational learning dimension in Saudi educational institutions.

3. There is a statistical significance of the educational leaders' commitment at sig. $(\alpha=0.05)$ to the competitiveness and organizational excellence dimension in Saudi educational institutions.

\section{Study limitations}

Spatial limitation: this study took place in the Faculty of Education of Ha'il University.

Human limitation: this study population is represented in a study case of all the educational leaders and teaching board members in the Faculty of Education of Ha'il University.

Time limitation: This study was accomplished in the academic year (2017/2018).

Scientific limitation: This study focuses on identifying the organizational intelligence dimensions in Saudi organizational institutions and the main trends that handled the concept of organizational intelligence

\section{Definitions of study terms}

Educational leaders: The activity of the educational administrative leaders in the areas of decision-making, issuing orders and the administrative supervision of others using an official authority along with influence and attraction in order to achieve a specific goal and the educational leadership. This concept combines between using the official authority inside educational institutions and the influence over others behavior to cooperate to achieve the goal. (Bilhasan, Bilqasem, 2014)

Educational institutions: This is a place or location in which groups of different ages meet, get educated and provided with a lot of information depending on the educational institution type. This educational institution consists of the teaching board members, students, parents and its administrative bodies. Students stay in this institution to receive knowledge for certain periods of time. These periods depend also on the educational institution type. As for there are different types of educational institutions, such as kindergartens, schools, institutes, colleges and universities. The importance of the educational institution (Marjani \& Soheilipour, M. 2012)

Organizational intelligence: is the organization ability to mobilize all its available mental forces and focus on the mind's ability to achieve this task. 
It is also an indicator to successfully measure businesses' crises management. (Albercht, 2002)

Knowledge management: is one of the organizational intelligence dimensions, represented in the member's ability of knowledge acquisition, in order to learn and adapt with the surrounding environment. (Nasir, 2014)

Organizational learning: is one of the organizational intelligence dimensions. It is considered the main tool to adapt to modern developments. (Nasir, 2014)

Competitiveness and organizational excellence: is one of the organizational intelligence dimensions. It expresses the degree of knowing the competitors and being ahead of them through collecting data and accurate knowledge. (Nasir, 2014)

\section{The study theoretical framework}

Organizational intelligence is one of the main inputs that try to use the intellectual capital in a positive effective way. It is represented through the mutual knowledge and experiences of the organization's members. Recently, more focus has been paid for the intellectual dimension in educational institutions, and for efficiency by which the organization's human resources can be exploited optimally. Educational institutions redefined themselves and their activities more clearly so all its internal and external parties can benefit.

We can say that organizational intelligence is based on the group ability to learn, spread and apply knowledge with efficiency and excellence. Organizational intelligence helps in developing the areas of planning and decision making through collecting and analyzing data, then take the appropriate decision and apply it. This helps the institution assess the organization's entrepreneurial capacity, understand the mutual relations between the institution and the environment, and then identify the needed enhancements in the institution's sub-systems to support innovation.

\section{Organizational intelligence concept}

The Latin word (intelligence) were first used by the Romanian philosopher (Cioran), later on it became common in English and French. Linguistically it means mind, intellectuality and wisdom. The mental activity was not restricted to psychologists only, but also was previously addressed by philosophers. They followed the intellectual observation approach which was adopted by psychologists before it became an experimental science. (Shahin, 2007)

Abdullah (2011) indicated that the word intelligence (Thaka') is derived from the verb (Thaka). In Al-Waseet lexicon, the root of this word had several meanings: "The fire's getting stronger" or "smartness". 
(Saleh et al., 2010) indicated that organizational intelligence leads to intelligent smart outcomes that can be applied in taking decisions, and that this type of intelligence comes from executive information systems' activities. It is used to describe direct data processing or data collecting activities.

The intelligent organization is: "an organization that has the responsibility to make decisions of strategic nature, which result in the generation and effective use of opportunities, and in reflecting the organization's value". (Matheson, 1998)

It was identified by (Hanebeck, 2000) as: "an organization that integrates its various organizational processes, in particular, its strategies, structure and its workers within its organizational framework".

(Filos, 2005) also identified it as: "an organization that has the ability to be agile due to its rapid generation of knowledge and benefiting from this knowledge in taking advantage of the available opportunities on one hand, and the rapid adaptation to challenges on the other hand".

Finkelstein \& Jackson (2005) defined it as: "an organization of high performance, its main objectives is achieving flexibility, knowledge and skillful workers".

(Saleh et al., 2010) defined it as "organizations that care about investing their workers mental abilities and the available information technology, through a high value system relies on transparency and sharing information, and renounces hierarchical structures and centrality as main principles.

Through the previous definitions, we can say that the intelligent organization is: an organization that makes use of all its employees' mental abilities to face challenges and improve the organization's performance as a whole, away from centrality and hierarchy, by allowing all employees to innovate, develop, and contribute in the decision making process and results' evaluation.

\section{The main trends that handle the concept of organizational intelligence}

1. The cognitive perspective: organizational intelligence is defined here as the ability of the institution to collect, process, analyze and exploit information to build new knowledge on which to act.

2. The behavioral perspective: organizational intelligence is represented here through the response toward the surrounding changes with the aim of positive adaptation and organizational behavior modification, in line with these changes.

3. The social perspective (sentimental): organizational intelligence is defined here as the ability to understand and evaluate the individual and others feelings, to guide the social relations properly. 


\section{Organizational intelligence dimensions}

There are several views about the organizational intelligence dimensions. But, there are three essential dimensions on which organizational intelligence is based (Nasir, 2014). They can be addressed through the following context:

1. Knowledge management: knowledge management represents one of the most important dimensions of organizational intelligence. There is a need for processes and systems that facilitate the creation and generation of knowledge, and its application in different situations or solving limited problems. Knowledge includes an implicit component of the individuals' skills and capabilities. These capabilities depend on the institutional and cultural situation in which knowledge is being created to benefit from it. This includes the mechanisms of coordination, organization, cooperation and the level of correlation between the organization and the surrounding environment. Organizational knowledge is defined as: "information that is associated with experience and context through interpretation and analysis. It is one of the highly evaluated aspects of information that can be applied and exploited in decisions and executive procedures.

2. Organizational learning: In order for an organism to survive, its learning rate must be equal to or higher than the rate of changing in the environment in which it lives. Organizations and institutions, like the living organism, have to increase their learning rate to maintain their survival in times of unprecedented change. Learning is the main mean of adapting to the age of knowledge in which we live. Knowledge acquired through learning, helps the learner to reform or change the environment. Learning and change support each other, and the faster the change is the more it is necessary to create a greater knowledge that helps in adapting to this change. This is the essence of the organizational intelligence.

3. Competitiveness and organizational excellence: Competitive advantage means the organization's self-possessed capabilities (skills, technology and resources), which can be employed and invested, in order to achieve higher benefit and value, and distinguish the organization from the rest of the competitors. It can also be said that, the outstanding organizational performance of educational institutions is not an option any more, it is an inevitability imposed by many circumstances and external forces. Excellence has no limits or constrains, it is an intellectual style that can occur in big or small organizations, governmental or private, that provide a service or a product. Competitiveness can be determined by the organization or the institution's proficiency in studying the current features of the current situation, benefiting from them, and turning them into ideas in progress. 


\section{Analyzing and testing the hypotheses}

Study methodology: the researcher used the analytical descriptive approach in collecting and analyzing data. He also distributed a questionnaire over the study sample to collect data. Then, he reached his results after analyzed the data and testing the hypotheses.

\section{Study population, sample and inspection unit}

The study population was made of all the educational leaders and teaching board members in the Faculty of Education of Ha'il University; (365) employees, males and females.

\section{Study sample}

The study tool has been distributed over a random sample of educational leaders (General Manager, Dean, Under Secretary, Head of Department), as well as the teaching board members of different specialties, to reach the final sample of (102) employees. The following table shows the distribution of the sample members in terms of (gender, academic rank and position).

The first table: study sample members' distribution

\begin{tabular}{cccc}
\hline \multicolumn{2}{c}{ According to } & Number & Percentage \\
\hline Gender & Male & 44 & $43.13725 \%$ \\
& Female & 58 & $56.86275 \%$ \\
$\begin{array}{c}\text { Academic } \\
\text { qualification }\end{array}$ & Professor & 3 & $2.941176 \%$ \\
Academic rank & & & \\
& Associate professor & 10 & $9.803922 \%$ \\
& Assistant professor & 50 & $49.01961 \%$ \\
& Lecturer & 15 & $14.70588 \%$ \\
& Teacher & 7 & $6.862745 \%$ \\
Position & Assistant teacher & 20 & $19.60784 \%$ \\
& General Manager & 1 & $0.980392 \%$ \\
& Dean & 6 & $5.882353 \%$ \\
& Under Secretary & 7 & $6.862745 \%$ \\
& Head Department & 12 & $11.76471 \%$ \\
& Teaching board & 76 & $74.5098 \%$ \\
& Total & & 102 \\
\hline
\end{tabular}

By the researcher (2017)

Given the distribution of the study sample, we conclude that the sample represents different variables and has the complete knowledge and experience to answer the study tool articles. This will empower the study results through its tool and its mechanism of implementation. 


\section{Data sources}

1. A research, in books, studies and articles related to the study subject, has been carried on.

2. The study tool has been used to collect digital data from the responses of the study members.

\section{Study tool}

The researcher has designed a questionnaire of (21) articles, depending on Likert Scale, divided as the following:

1. Seven articles about the knowledge management dimension.

2. Seven articles about the organizational learning dimension.

3. Seven articles about the competitiveness and organizational learning dimension.

\section{The study tool reliability}

The researcher used Cronbach's alpha coefficient, test and re-test, in a period of two weeks over a sample of (30) members of the study population, other than the original study sample, to calculate the study coefficient of reliability. The result was (88.4).

\section{Statistical processing}

The researcher used the statistics software (SPSS) and also applied (one sample T-test).

Comparison criterion of the study main hypothesis:

\begin{tabular}{ccc}
\hline No. & Range & Level of commitment \\
\hline $\mathbf{1}$ & $21-48.5$ & Low \\
$\mathbf{2}$ & $49-76.5$ & Medium \\
$\mathbf{3}$ & $77-105$ & High \\
\hline
\end{tabular}

Comparison criterion of the study sub-hypotheses:

\begin{tabular}{ccc}
\hline No. & Range & Level of commitment \\
\hline $\mathbf{1}$ & $7-16.32$ & Low \\
$\mathbf{2}$ & $16.33-25.65$ & Medium \\
$\mathbf{3}$ & $25.66-35$ & High \\
\hline
\end{tabular}

\section{Results of the study hypotheses}

$0 \mathrm{H}$ : There is commitment of statistical significance at sig. $(\alpha=0.05)$ of the educational leaders to the organizational intelligence dimensions in Saudi educational institutions. 
The second table: (T-test) results of the main hypothesis

\begin{tabular}{cccccc}
\hline Number & $\begin{array}{c}\text { Arithmetic } \\
\text { average }\end{array}$ & $\begin{array}{c}\text { Standard } \\
\text { deviation }\end{array}$ & T & df & Sig(2-tailed) \\
\hline $\mathbf{1 0 2}$ & 85.68 & 6.105 & 78.15 & 101 & 0.000 \\
\hline
\end{tabular}

From the previous table we see that the calculated value (78.15) of (T) is bigger than the (T) table value (1.98). Based on this we accept the study alternative hypothesis; in general, there is commitment of the educational leaders to the organizational intelligence dimensions from the perspective of teaching board members and the educational leaders as well. If we go back to the comparison criterion, we see that the level of commitment is high; this shows the awareness of educational leaders toward the organizational intelligence in the management process of Saudi educational institutions.

H01: there is commitment of statistical significance at sig $(\alpha=0.05)$ of the educational leaders to the knowledge management dimension in Saudi educational institutions.

The third table: (T-test) results of the first sub-hypothesis

\begin{tabular}{cccccc}
\hline Number & $\begin{array}{c}\text { Arithmetic } \\
\text { average }\end{array}$ & $\begin{array}{c}\text { Standard } \\
\text { deviation }\end{array}$ & T & df & Sig(2-tailed) \\
\hline $\mathbf{1 0 2}$ & 32.47 & 2.08 & 24.84 & 101 & 0.000 \\
\hline
\end{tabular}

From the previous table we see that the calculated value (24.84) of (T) is bigger than the (T) table value (1.98). Based on this we accept the study alternative hypothesis; there is commitment of the educational leaders to the knowledge management dimension from the perspective of teaching board members and the educational leaders as well. If we go back to the subcomparison criterion, we see that the level of commitment is high.

H02: there is commitment of statistical significance at sig $(\alpha=0.05)$ of the educational leaders to the organizational learning dimension in Saudi educational institutions.

The forth table: (T-test) results of the second sub-hypothesis

\begin{tabular}{cccccc}
\hline Number & $\begin{array}{c}\text { Arithmetic } \\
\text { average }\end{array}$ & $\begin{array}{c}\text { Standard } \\
\text { deviation }\end{array}$ & $\mathbf{T}$ & df & Sig(2-tailed) \\
\hline $\mathbf{1 0 2}$ & 28.87 & 2.04 & 15.64 & 101 & 0.000 \\
\hline
\end{tabular}

From the previous table we see that the calculated value (15.64) of (T) is bigger than the (T) table value (1.98). Based on this we accept the study alternative hypothesis; there is commitment of the educational leaders to the organizational learning dimension from the perspective of teaching board members and the educational leaders as well. If we go back to the subcomparison criterion, we see that the level of commitment is high.

H03: there is commitment of statistical significance at sig $(\alpha=0.05)$ of the educational leaders to the competitiveness and organizational excellence dimension in Saudi educational institutions. 
The fifth table: (T-test) results of the third sub-hypothesis

\begin{tabular}{cccccc}
\hline Number & $\begin{array}{c}\text { Arithmetic } \\
\text { average }\end{array}$ & $\begin{array}{c}\text { Standard } \\
\text { deviation }\end{array}$ & $\mathbf{T}$ & df & Sig(2-tailed) \\
\hline $\mathbf{1 0 2}$ & 27.98 & 1.985 & 13.69 & 101 & 0.000 \\
\hline
\end{tabular}

From the previous table we see that the calculated value (13.69) of (T) is bigger than the (T) table value (1.98). Based on this we accept the study alternative hypothesis; there is commitment of the educational leaders to the competitiveness and organizational excellence dimension from the perspective of teaching board members and the educational leaders as well. If we go back to the sub-comparison criterion, we see that the level of commitment is high.

\section{Study results}

1. Educational leaders are committed to the organizational intelligence dimensions in Saudi educational institutions with a high noticeable level.

2. Educational leaders are committed to the knowledge management dimension in Saudi educational institutions with a high level.

3. Educational leaders are committed to the organizational learning dimension in Saudi educational institutions with a high level.

4. Educational leaders are committed to the competitiveness and organizational excellence dimension in Saudi educational institutions with a high level.

\section{Conclusion}

1. Organizational intelligence dimensions are one of the most important dimensions that educational leaders must work through to ensure the progress of educational institutions and keep pace with the scientific revolution in the world.

2. The policies pursued by the educational leaders in educational institutions are the main engine of scientific progress.

3. It is the responsibility of the educational leaders in scientific institutions to pay the effort searching for supporting strategies and programs to enhance the process of learning and education in their institutions.

\section{Recommendations}

1. The importance of generalizing the current experience in the Faculty of Education at Ha'il University over the rest of the university's faculties.

2. Work on supporting the scientific revolution in the Faculty through clarifying the importance of organizational intelligence to the rest of the institution's working members.

3. Continue following an approach of exploiting the institution's human resources. 
4. The need to depend on a balanced performance in order to increase the institution's development.

\section{References:}

1. Abdullah, Mohammad Hasan. (2011), Intelligence between Unilateralism and Pluralism, Atirak for Printing, Publishing and Distribution, Cairo, Egypt.

2. Al-Abadi, Hashem Fawzi. (2012). Organizational Intelligence as a Business Practice towards Building an Intelligent Organization: A Conceptual Perspective. "A Paper at the Eleventh Annual Scientific Conference, Business Intelligence and Knowledge of Economy, 23-26 April, Zaytoonah University, Amman, Jordan.

3. Albrecht, K. (2002)."Organizational intelligence \& knowledge management: Thinking outside the silos". Available online.http//www. karlalbrecht. comon August, 12, 2010.

4. Bilhasan, Ali, Bilqasim, Adwan, (2014). Educational Leadership, The Instructive Regional Media Forum of the South, held in Abi Bakr Al Haj Issa High School, Laghouat, Algeria.

5. Durrah, Abdulbari. (2015). "The Arab Contemporary intelligent Organization and the Role of Integrated Talent Management in Achieving its Objectives ", The 21st Arab International Conference for Training and Administrative Development, 17-19 November, 2015, Arab Experts in Engineering and Management, Cairo, Egypt.

6. Filos, Erastos; Dec. 2005. Smart Organizations In The Digital Age. European Commission, Directorate-General Information Society and Media. Cited on 24th May 2006. Available: http://www.veforum. org/apps/recview.asp?P=Article\&T = Articles\&Q=54.

7. Finkelstein, Sydney and Jackson, Eric M.; Sep/Oct 2005. Immunity from implosion: Building smart leadership. Ivey Business Journal; Vol. 70 Issue 1, p1-7. Cited on 24th May 2006. Available: EBSCO host. Html.

8. Hanebeck, H., Ch., (2000), "Business processes for a distributed learning environment", Turkish online journal of distance education TOJDE , January, 2000 ISSN 1302-6488, Vol. 1 , No. 1 , Article No.: 4 , P.P. 26-36.

9. Hanounah, Sami \& Hammad, Ibrahim, (2006). Measuring the Level of Organizational Commitment of University Workers (unpublished master thesis), Islamic University, Gaza, Palestine.

10. Marjani, A. B., \& Soheilipour, M. (2012)."The Relationship between Organizational Intelligence and Staff Performance Based on the Model of Karl Albrecht". International Journal of Business and Social Science , 3(4), 152-158. 
11. Matheson, David and Matheson, James E.; 1998. The Smart Organization: Creating Value through Strategic R\&D. Harvard Business School Press. Boston. USA.

12. Nasir, Azza Jalal Mustafa. (2014). Intellectual Assets Management: Strategical Perspective, Alnahil for Publishing.

13. Saleh, Ahmed Ali, Al-Azzawi, Bushra Hashim, Ibrahim, Ibrahim Khalil. (2010), Intelligent Management for Strategic and Social Excellence Approach in Organizations, Dar Wael for Publishing \& Distribution, Amman, Jordan.

14. Shahin, Mazen Ismail. (2007), Assessment of the Benefits of Business Intelligence Systems in Creating Value for Organizations, unpublished master thesis, Faculty of Management and Economics, University of Baghdad.

\author{
Annex \\ Annex number(1) \\ Dear sir or madam/ \\ Peace be upon you and May Allah bestow you with his bless and mercy. \\ To proceed, \\ I would appreciate your cooperation in completing this study by filling out the attached \\ questionnaire under the subject: The Level of Educational Leaders' Commitment to the \\ Organizational Intelligence Dimensions in the Saudi Educational Institutions. (Case \\ study in Ha'il University/ Faculty of Education) \\ All your provided information is strictly confidential and will be only used for scientific \\ research purposes. We promise to provide you with a copy of the research results once they \\ are completed. \\ Yours sincerely, \\ Researcher: \\ khawla Husain alaiwa \\ Assistant professor- University of hail \\ Phone number: 00966562499005
}

First: demographic data

Gender:male ( ) female ( )

The academic rank:

Professor ( ) Associate Professor ( ) Assistant Professor ( )

Lecturer ( ) Teacher ( ) Assistant Teacher ( )

Position:

General Manager ( ) Dean ( ) Under Secretary ( )

Head of Department （ ) Teaching board member ( )

\title{
Second: The study tool articles
}




\begin{tabular}{|c|c|c|c|c|c|c|}
\hline No. & Article & $\begin{array}{c}\text { Strongly } \\
\text { agree }\end{array}$ & Agree & Neutral & $\begin{array}{l}\text { Don't } \\
\text { agree }\end{array}$ & $\begin{array}{c}\text { Strongly don't } \\
\text { agree }\end{array}$ \\
\hline \multicolumn{7}{|c|}{ First dimension: knowledge management } \\
\hline 1 & $\begin{array}{l}\text { Educational leaders in my } \\
\text { organization focus on } \\
\text { acquiring new knowledge }\end{array}$ & & & & & \\
\hline 2 & $\begin{array}{l}\text { Educational leaders in the } \\
\text { institution facilitate the } \\
\text { process of generating } \\
\text { knowledge and applying it } \\
\text { in most educational fields }\end{array}$ & & & & & \\
\hline 3 & $\begin{array}{l}\text { Educational leaders have } \\
\text { many mechanisms of } \\
\text { coordination and } \\
\text { organization among } \\
\text { different departments } \\
\end{array}$ & & & & & \\
\hline 4 & $\begin{array}{l}\text { Educational leaders are } \\
\text { strongly correlated with } \\
\text { the external environment }\end{array}$ & & & & & \\
\hline 5 & $\begin{array}{c}\text { Members of the institution } \\
\text { share a set of mutual } \\
\text { beliefs and relationships }\end{array}$ & & & & & \\
\hline 6 & $\begin{array}{l}\text { Educational leaders in my } \\
\text { institution have the needed } \\
\text { skills and abilities to } \\
\text { manage the institution }\end{array}$ & & & & & \\
\hline 7 & $\begin{array}{l}\text { Educational leaders take } \\
\text { into account intangible } \\
\text { assets in the institution in } \\
\text { which I work }\end{array}$ & & & & & \\
\hline \multicolumn{7}{|c|}{ The second dimension: the organizational learning } \\
\hline 1 & $\begin{array}{c}\text { There is a noticeable } \\
\text { increase in the } \\
\text { institution's learning rate }\end{array}$ & & & & & \\
\hline 2 & $\begin{array}{l}\text { Educational leaders } \\
\text { remarkably benefit from } \\
\text { the gained knowledge }\end{array}$ & & & & & \\
\hline 3 & $\begin{array}{c}\text { The organizational } \\
\text { behavior in the institution } \\
\text { is of rapid change and } \\
\text { modification }\end{array}$ & & & & & \\
\hline 4 & $\begin{array}{l}\text { Educational leaders in the } \\
\text { institution have a high } \\
\text { competitive advantage } \\
\text { compared to other } \\
\text { institutions }\end{array}$ & & & & & \\
\hline 5 & $\begin{array}{c}\text { Educational leaders in the } \\
\text { institution exchange and } \\
\text { share knowledge among } \\
\text { themselves }\end{array}$ & & & & & \\
\hline 6 & $\begin{array}{c}\text { Educational leaders rely } \\
\text { on a potential organization } \\
\text { in the human resources of } \\
\text { the institution }\end{array}$ & & & & & \\
\hline 7 & $\begin{array}{l}\text { Educational leaders help } \\
\text { transfer individual } \\
\text { experiences and } \\
\text { knowledge to other } \\
\text { members of the institution }\end{array}$ & & & & & \\
\hline \multicolumn{7}{|c|}{ The third dimension: the competitiveness and organization } \\
\hline
\end{tabular}




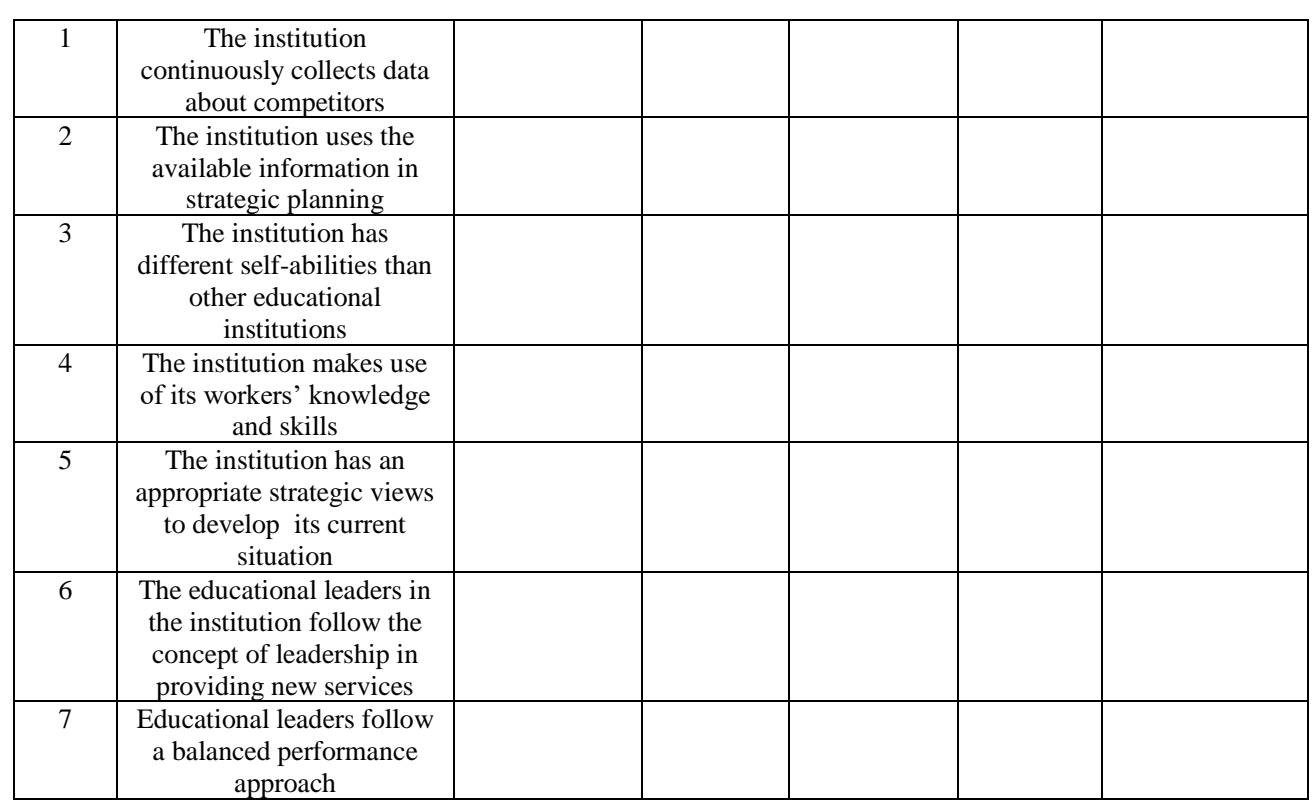

